ББК 63.4

\author{
Организация конференциии и издание материалов проведень \\ при финансовой поддержке Российского фонда фундаментальных исследований, \\ проект № 19-09-20008
}

Утверждено к печати Ученым советом ИИМК РАН

Редакционная коллегия тома I: В. А. Алёкшин, Л. Б. Кирчо (отв. редакторы),

В. П. Никоноров, В. Я. Стёганцева; В. В. Терёхина

Рецензенты: д. и. н. Л. Б. Вишняцкий, д. и. н. А. А. Выборнов

Программный комитет конференции: академик РАН, д. и. н., проф. М. Б. Пиотровский

(Государственный Эрмитаж, почетный председатель); д. и. н. В. А. Лапшин (ИИМК РАН, председатель); д. и. н. А. В. Головнёв (МАЭ РАН, сопредседатель); д. и. н. В. А. Дергачёв (Высшая антропологическая школа, Молдова, сопредседатель); д. и. н. И. Ф. Попова (ИВР РАН, сопредседатель); академик АН Республики Узбекистан, д. и. н., проф. Э. В. Ртвеладзе (сопредседатель); к. и. н. А. В. Поляков (ИИМК РАН, зам. председателя); к. и. н. В. А. Алёкшин (ИИМК РАН, зам. председателя); д. и. н. Ю. Е. Берёзкин (МАЭ РАН); Dr., Prof. Н. Бороффка (Германский археологический институт, Германия); В. С. Бочкарёв (ИИМК РАН); Dr. Э. Кайзер (Свободный университет Берлина, Германия); к. и. н. М. Т. Кашуба (ИИМК РАН); д. и. н. Л. Б. Кирчо (ИИМК РАН); к. и. н. А. В. Кияшко (Южный федеральный университет); к. и. н. П. Ф. Кузнецов (СГСПУ);

к. и. н. Н. М. Малов (СНИГУ); к. и. н. В. П. Никоноров (ИИМК РАН); Ю. Ю. Пиотровский

(Государственный Эрмитаж); д. и. н., проф. Д. Г. Савинов (Институт истории СПбГУ);

к. и. н. В. Н. Седых (Институт истории СПбГУ); к. и. н. Н. Н. Скакун (ИИМК РАН);

к. и. н. Н. Ф. Соловьёва (ИИМК РАН); к. и. н. А. И. Торгоев (Государственный Эрмитаж); к. и. н. Е. А. Черлёнок (Институт истории СПбГУ)

Организационный комитет конференции: к. и. н. А. В. Поляков (ИИМК РАН, председатель);

к. и. н. В. А. Алёкшин (ИИМК РАН, зам. председателя); В. С. Бочкарёв (ИИМК РАН); ); к. и. н. М. Т. Кашуба (ИИМК РАН); д. и. н. Л. Б. Кирчо (ИИМК РАН);

А. И. Климушина (ИИМК РАН, отв. секретарь); к. и. н. В. П. Никоноров (ИИМК РАН); Ю. Ю. Пиотровский (Государственный Эрмитаж); В. Я. Стёганцева (ИИМК РАН); В. В. Терёхина

(ИИМК РАН, МАЭ РАН, отв. секретарь); к. и. н. Е. С. Ткач (ИИМК РАН); И. Ж. Тутаева (Государственный Эрмитаж); к. и. н. Е. А. Черлёнок (Институт истории СПбГУ)

Древности Восточной Европы, Центральной Азии и Южной Сибири в контексте связей и взаимодействий в евразийском культурном пространстве (новые данные и концепции): Материалы Международной конференции, 18-22 ноября 2019 г., Санкт-Петербург. Т. I. Древняя Центральная Азия в контексте евразийского культурного пространства (новые данные и концепции). К 90-летию со дня рождения патриарха евразийской археологии Вадима Михайловича Массона. - СПб.: ИИМК РАН, Невская Типография, 2019. — 291 с.

ISBN 978-5-907053-34-2

DOI 10.31600/978-5-907053-34-2 
size of the raw materials, some of the cores were made of flakes; perhaps, this is a consequence of the desire to unify the industry, aimed at obtaining microblades of a certain size. This does not contradict the variety of core forms: the removals from all the types of cores are uniform, the type of each core depends, apparently, solely on the parameters of the raw materials.

\title{
MULTI-LAYER PREHISTORIC SITE IN SOUTH TURKMENISTAN - DASHLY DEPE
}

\author{
Aydogdy Kurbanov*, Nikolaus Boroffka ${ }^{\star *}$ \\ ${ }^{*}$ German Archaeological Institute, Eurasian department, Visiting research fellow, Ashgabat, \\ Turkmenistan; ${ }^{* *}$ German Archaeological Institute, Eurasian department, Research fellow, \\ Berlin, Germany
}

DOI: $10.31600 / 978-5-907053-34-2-26-28$

Keywords: Eneolithic, Bronze Age, Early Iron Age, Central Asia, Turkmenistan.

The site of Dashly Depe (fig. 1) lies in the center of Yzgant in the Ahal province of Turkmenistan. The locality is situated on the floodplain north of the Kopetdag Mountains, about $35 \mathrm{~km}$ northwest of Ashgabat, the modern capital of Turkmenistan. The mound visible today has a size of ca. $100 \times 150 \mathrm{~m}$, being oval in north-south direction, and with a preserved height of around $3 \mathrm{~m}$. The upper layers have been damaged by various works in modern times, and parts of the mound have been disturbed due to the exploitation of clay for building material. It is very likely that the mound is in fact considerably larger and much of it has been buried by alluvial sediments which cover the entire plain.

Only few mentions of the site may be found in the older archaeological literature: (Хлопин 1960; 1963; Лисицина 1978: рис. 3; Kohl 1984: 213). Researchers dated the site to the Anau IA Namazga I period (earliest Chalcolithic) and to the Anau IV time (earliest Iron Age, now mostly named Yaz I period).

After a visit by the authors in 2011, during which some pottery could be collected from the surface of the site, it was confirmed that there is material of the early Chalcolithic (Anau IA Namazga I), while early Iron Age pottery (Yaz I type) was not found at all. Instead there is wheelmade pottery of light beige color, which is quite typical of the Bronze Age (Namazga V-VI), well

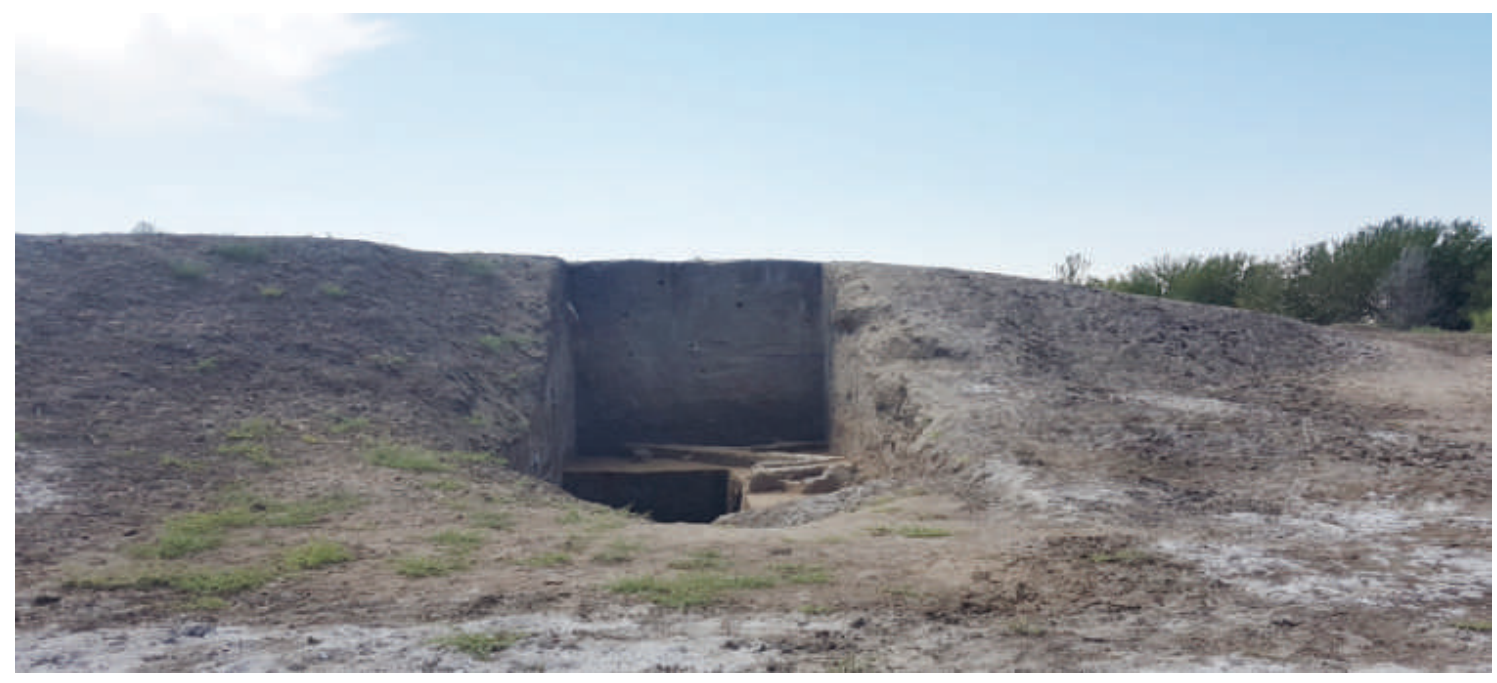

Fig. 1. Dashly Depe seen from the north 
known from most of Turkmenistan, but especially from such sites as Altyn Depe, Gonur Depe or Togolok (Массон 1981; Сарианиди 1990).

In spring 2012 excavations were started in Dashly Depe by the researchers of the Institute of Archaeology and Ethnography of the Academy of Sciences of Turkmenistan in cooperation with the German Archaeological Institute and by financial support of a National Geographic grant. The initially small stratigraphic trench, which was begun on a surface of $2 \times 6 \mathrm{~m}$ in 2012 , has been extended towards the north. It was dug in artificial spits (Russian yarus) of $50 \mathrm{~cm}$ thickness and has reached a depth of over $5 \mathrm{~m}$ without exposing the sterile ground, which must lie even deeper. Since this is already $2 \mathrm{~m}$ below the surrounding plain, the idea expressed above, that alluvial sediments cover much of the site, has already been confirmed. The top layer is disturbed by later activity and contains material from the Chalcolithic, the Bronze Age (wheel-made pottery) and modern times mixed up. The levels below the artificial spits VI-VII are clearly still cultural layers, none of them being of natural formation. In artificial spit VIII there are even indications of another beaten clay floor, and pottery is found down to the lowest layer uncovered so far. However, due to the small excavation area at this depth, there is not enough archaeological material yet to follow the evolution further backwards it may only be said that the layers are, of course, older and could well be from the Neolithic period. However, this may be demonstrated only by further research (Boroffka, Kurbanov 2015).

During the 2018 excavation season pottery similar to material of the Yaz II was found in a trench at the top of the mound. After several seasons Dashly Depe, being a unique site in this region, demonstrates a chronological sequence from the Eneolithic period up to the Early Iron Age.

\section{References}

Лисицина Г. Н. 1978. Становление и развитие орошаемого земледелия в Южной Туркмении. М. Массон В. М. 1981. Алтын-Депе. Л. (Тр. ЮТАКЭ. Т. 18).

Хлопин И. Н. 1960. Дашлыджи-депе и энеолитические земледельцы Южного Туркменистана // Массон М. Е. (ред.). Тр. ЮТАКЭ. Ашхабад. Т. 10. С. 134-224.

Хлопин И. Н. 1963. Памятники раннего энеолита Южной Туркмении. М.; Л. (Археология СССР. САИ. Вып. Б3-8).

Сарианиди В. И. 1990. Древности страны Маргуш. Ашхабад.

Boroffka N., Kurbanov A. 2015. New data on the Neolithic and Eneolithic of Central Asia: Dashlydepe (Turkmenistan). In: Miras. 1. P. 38-55.

Kohl Ph. L. 1984. Central Asia: Palaeolithic beginnings to the Iron Age. Paris (Recherche sur les Civilisations. Synthèse. 14).

\section{ДАШЛЫ-ДЕПЕ - МНОГОСЛОЙНЫЙ ДОИСТОРИЧЕСКИЙ ПАМЯТНИК НА ЮГЕ ТУРКМЕНИСТАНА}

\section{А. Курбанов ${ }^{\star}$, Н. Бороффка ${ }^{* \star}$}

* Германский археологический институт, Евразийский отдел, приглатенный научный сотрудник; Ашхабад, Туркменистан; ${ }^{* *}$ Германский археологический институт, Евразийский отдел, Берлин, Германия

Ключевые слова: энеолит, бронзовый век, ранний железный век, Центральная Азия, Туркменистан.

Древнее поселение Дашлы-депе, расположенное на окраине с. Изгант, примерно в 35 км к С3 от столицы Туркменистана Ашхабада, является очень важным памятником, хронологически охватывающим, судя по всему, время перехода от неолита к энеолиту в подгорной 
полосе Центрального Копетдага. Радиоуглеродные даты дали новые данные по истории этого поселения и подтверждают вероятность того, что оно возникло в период неолита (джейтунская культура). Уже раскопанные там слои хронологически пересекаются со всеми ранними периодами культуры Анау (конец V-IV тыс. до н. э.), но показывают даже более четкие традиции неолита в материальной культуре, чем Анау. В энеолитическую эпоху (Намазга I-II) жизнь на Дашлы-депе, по-видимому, продолжалась без какого-либо видимого серьезного перерыва, и поэтому переходный этап от неолита к энеолиту вполне доступен для изучения - ситуация, весьма редкая для первобытной археологии Центральной Азии.

В настоящее время Дашлы-депе представляет собой один из самых западных ранних памятников позднеджейтунской и ранней намазгинской культур, и это обстоятельство дает возможность изучения контактов его населения с носителями синхронных культур долины Сумбара на западе Туркменистана.

\title{
ОГОНЬ В ЖИЗНИ РАННИХ ЗЕМЛЕДЕЛЬЦЕВ ЮЖНОГО ТУРКМЕНИСТАНА ${ }^{1}$
}

\author{
Н. Ф. Соловьёва, Е. К. Блохин \\ Институт истории материальной культуры РАН, Санкт-Петербург, Россия
}

DOI: $10.31600 / 978-5-907053-34-2-28-29$

Ключевые слова: Центральная Азия, Южный Туркменистан, Йылгынлы-депе, энеолит, ранние земледельиьь, очаги.

В результате археологического изучения поселений ранних земледельцев на территории Южного Туркменистана, проводимых либо начатых под руководством В. М. Массона учеными ИИМК РАН (ранее - ЛОИА АН СССР), накоплен большой объем информации, раскрывающий ключевые моменты повседневной жизни раннеземледельческих обществ региона. Обширный массив данных свидетельствует о роли огня в быту и обрядах обитателей поселений эпохи палеометалла. Недавнее открытие в горизонте конца периода раннего энеолита на поселении Йылгынлы-депе уникальной мастерской по изготовлению мелкой глиняной пластики с двумя обжигательными печами делает особенно актуальным сбор сведений о местах разведения огня и создание типологии таких объектов. Говоря о всем корпусе источников в целом, мы используем термин «место разведения огня», включающий любые типы очагов, печи, специально оформленные костры, ямки для огня, пятна прокала и т. п. Уже сейчас представляется возможным предложить некоторые интерпретации выделенных нами типов.

Всего было учтено более 100 специально оформленных мест разведения огня открытых при раскопках поселений на территории Южного Туркменистана, датирующихся эпохами неолита и энеолита, большая часть которых опубликована. Основным источником послужили прекрасно сохранившиеся и тщательно исследованные на протяжении 25 полевых сезонов закрытые комплексы поселения Йылгынлы-депе. В качестве аналогий привлечены подобные описанным энеолитические объекты из Ирана, Сирии, Ирака и Южной Анатолии, а также печи эпохи бронзы из поселений, исследованных на территории Туркменистана. Кроме того, при интерпретации изучаемых конструкций привлекались

${ }^{1}$ Работа выполнена в рамках программы ФНИ ГАН по теме государственного задания № 01842019-0011 «Развитие методики изучения и сохранения памятников истории и культуры». 